\title{
MENINGKATKAN KREATIVITAS DAN PEMAHAMAN KONSEP VOLUM DAN LUAS SISI BANGUN RUANG DENGAN PENDEKATAN KONTEKSTUAL
}

\author{
Sulaiman \\ SMP Negeri 2 Pasongsongan Sumenep
}

\begin{abstract}
ABSTRAK
Penelitian ini adalah Penelitian Tindakan Kelas (PTK) yang bertujuan untuk mengetahui apakah ada peningkatan kreativitas dan pemahaman siswa terhadap konsep volum dan luas sisi bangun ruang dengan pendekatan pembelajaran kontekstual. Peneltian ini dilaksanakan di SMP Negeri 2 Pasongsongan dengan subyek penelitian siswa kelas 3 pada semester I tahun pelajaran 2012/2013. Pada penelitian tindakan kelas ini direncanakan tindakan sebanyak 2 siklus, dimana setiap siklus terdiri dari rangkaian kegiatan : (1) perencanaan; (2) pelaksanaan; (3) observasi; (4) analisis data; (5) refleksi. Hasil penelitian ini memberikan data bahwa kerativitas siswa meningkat pada siklus II $26(67,7 \%)$ siswa baik, 9(24,1\%) siswa cukup dan hanya 3(8,2\%) siswa kreativitasnya masih kurang. Sebanyak 34 (89,5\%) siswa merasakan, bahwa pembelajaran dengan pendekatan kontekstual menyenangkan dan hanya 4 (10,5\%) siswa menyatakan bahwa pembelajaran dengan pendekatan kontekstual membosankan. Hal ini dapat dipahami karena hampir 33 $(86,8 \%)$ menyatakan bahwa pembelajaran volum dan luas bangun ruang dengan pendekatan kontekstual bermanfaat dalam kehidupannya dan hanya 5 (13,2\%) menyatakan tidak bermanfaat. Setelah mengalami pembelajaran volum dan luas bangun ruang dengan pendekatan kontekstual pemahaman konsep siswa terhadap volum balok, volum kubus dan volum prisma lebih baik. Hal ini ditunjukkan dari 38 siswa, 93\% mampu menjawab soal dengan benar dan hanya 7\% siswa mengalami kesulitan.
\end{abstract}

\section{Kata Kunci : Kreativias, Pemahaman, Kontekstual}

\section{PENDAHULUAN}

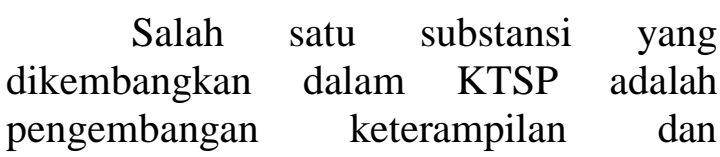
kecakapan hidup (life skills). Sehingga secara metodologis KBK menekankan pada penggunaan pendekatan, metode dan sumber belajar yang bervariasi serta pembelajaran yang harus berpusat pada anak. (Hamid Muhammad, 2004).

Pendekatan

kontekstual

merupakan suatu konsep belajar dimana guru menghadirkan situasi dunia nyata ke dalam kelas dan mendorong siswa membuat hubungan antara pengetahuan yang dimilikinya dengan penerapannya dalam kehidupan mereka sebagai anggota masyarakat. Proses pembelajaran berlangsung alamiah dalam bentuk kegiatan siswa bekeda dan mengalami, bukan transfer pengetahuan dari guru ke siswa. Pendektan kontekstual menekankan pentingnya lingkungan alamiah itu diciptakan dalam proses belajar agar kelas lebih "hidup" dan lebih "bermakna" karena siswa "mengalami" sendiri apa yang dipelajarinya. (Nurhadi, dkk, 2003).

Kata kunci pembelajaran kontekstual adalah : (1) real world learning; (2) mengutamakan pengalaman nyata; (3) berpikir tingkat tinggi; (4) berpusat pada siswa; (5) siswa aktif, kritis dan kreatif, (6) pengetahuan bermakna dalam kehidupan; (7) dekat dengan kehidupan nyata; (8) perubahan perilaku; (9) siswa praktek bukan menghafal; (10) learning bukan teaching; (11) pendidikan (education) bukan pengajaran (instruction). (12) pembentukan manusia; (13) memecahkan masalah; (14) siswa "akting" guru mengarahkan; (15) hasil 
belajar diukur dengan berbagai cara bukan hanya tes. (Nurhadi, dkk, 2003).

Ada tujuh komponen utama pembelajaran yang mendasari penerapan pembelajaran kontekstual dikelas. Ke tujuh komponen utama itu adalah (1) constructivism; (2) Questioning; (3) Inquiry; (4) Learning Community; (5) Modeling (6) Reflection (7) Authentic Assessment. Sebuah kelas dikatakan menggunakan pendekatan kontekstual jika menerapkan ke tujuh komponen tersebut dalam pembelajarannya. (Nurhadi, dkk, 2003).

Di dalam pasal 3 UU. No. 20 Tabun 2003 tentang sistem pendidikan nasional adalah mengembangkan potensi peserta didik agar menjadi manusia yang beriman dan bertaqwa kepada Tuhan Yang Maha Esa, berakhlak mulia, sehat, berilmu, cakap, kreatif, mandiri dan menjadi warga negara yang demokratis serta bertanggung jawab. Selanjutnya di dalam pasal 4 ayat 2 dinyatakan bahwa pendidikan diselenggarakan dengan memberi keteladanan, membangun kemauan dan mengembangkan kreativitas peserta didik dalam proses pembelajaran.

S.C. Utami Munandar (1992) dalam bukunya mengembangkan bakat dan kreativitas anak sekolah, merumuskan kreativitas adalah kemampuan untuk membuat kombinasi baru, berdasarkan data, informasi atau unsur-unsur yang ada. Selanjutnya dalam belajar kreatif siswa terlibat secara aktif dan mendalami bahan yang dipelajari (penalaran) tetapi juga berhubungan dengan penghayatan pengalaman belajar yang mengasyikkan.

$$
\text { Pentingnya kreativitas }
$$

dikembangkan karena : (1) dengan berkreasi orang dapat mewujudkan dirinya; (2) kreativitas atau berpikir kreatif sebagai kemampuan untuk melihat berbagai macam kemungkinan penyelesaian terhadap suatu masalah; (3) bersibuk diri dengan kratif tidak hanya bermanfaat, tetapi juga memberikan kepuasan kepada diri sendiri; (4) kreativitaslah yang memungkinkan manusia meningkatkan kualitas hidupnya (S.C. Utami Munandar, 1992).

Bobbi Deporter dan Mike Hernachi (2000) dalarn bukunya Quantum Learning mengemukakan bahwa seorang yang kreatif selalu mempunyai rasa ingin tahu, ingin mencoba, bertualang, suka bermain-main, intuisif, dan mempunyai potensi untuk menjadi orang yang kreatif Semua orang lahir dengan kreativitas dan jika ia yakin ia adalah orang yang kreatif maka ia akan menemukan cara yang kreatif untuk mengatasi masalah harian baik dalam pekerjaan maupun dalam kehidupan pribadinya.

Kreativitas pembelajaran yang dapat diciptakan oleh guru adalah menciptakan suasana pembelajaran yang menantang dan menyenangkan bagi siswanya.

Perilaku kreatif adalah hasil dari pemikiran kreatif Oleh karena itu, hendaknya sistem pendidikan dapat merangsang pemikiran, sikap dan perilaku kreatif produktif, disamping pemikiran logis dan penalaran (S.C. Utami Munandar, 1994).

Berdasarkan fungsi tersebut, siswa harus dapat memahami konsep-konsep dan prinsip-prinsip matematika secara, bermakna. Tanpa pemahaman seperti ini mustahil siswa dapat memecahkan masalah-masalah yang terkait dengan matematika.

Telah diketahui bahwa konsep-konsep matematika adalah abstrak, sedangkan siswa SMP belum mampu berabstraksi dengan baik. Dari kenyataan ini, konsep matematika yang abstrak tersebut hendaknya disajikan dengan menggunakan material konkrit (physical models) sebagai alat bantunya.

Untuk memahami suatu konsep, siswa perlu didorong untuk mengorganisasi, memproses, menyimpan dan mengungkapkan kembali struktur informasi atau pengetahuan yang telah diperolehnya. Secara umum kita membedakan konsep konkrit dan konsep abstrak. Konsep abstrak cenderung 
didefinisikan, dijelaskan dan dipelajari sebaliknya konsep konkrit realatif mudah dipelajari. Kunci untuk memahami strategi-strategi yang dipakai siswa untuk memperoleh konsep ialah dengan cara mereka itu mendekati atau memahami informasi yang ada melalui contoh-contoh. (Toto Sudiharto, dkk, 1998).

Strategi belajar konsep merupakan suatu alat untuk membantu siswa mengembangkan strategi berpikir. Konsep mungkin diajarkan dengan menggunakan pendekatan-pendekatan secara deduktif dan induktif.

Pemahaman konsep volum dan luas sisi bangun ruang dengan pendekatan kontekstual adalah strategi pengajaran konsep dengan menggunakan pendekatan induktif

Hasil observasi di SW Negeri 2 Pasongsongan Sumenep menunjukkan, bahwa kemampuan siswa dalam berkreativitas dan memahami konsep matematika masih kurang/redah. Hal ini dimungkinkan terjadi karena adanya, beberapa faktor, yaitu :

1) Model pembelajaran matematika yang terpaku pada pembelajaran yang statis dan monoton.

2) Pembelajaran yang dikembangkan/diciptakan tidak memberikan kesempatan kepada siswa untuk berkembang secara maksimal.

3) Motivasi belajar siswa terhadap matematika masih rendah.

4) Kemampuan dasar berhitung siswa yang rendah.

5) Masih banyaknya siswa yang beranggapan bahwa matematika itu sulit dan membosankan.

Penelitian ini merupakan

Penelitian Tindakan Kelas (PTK) yang telah penulis lakukan dalam proses pembelajaran dengan menggunakan pendekatan kontekstual (CTL) pada Pokok Bahasan Volum dan Luas Sisi Bangun Ruang kelas 3 semester I di SMP Negeri 2 Pasongsongan. Seringkali terjadi kesalahan perhitungan volum dan luas bangun ruang yang diakibatkan oleh kelemahan siswa dalam mengabstraksikan model-model bangun ruang. Pendekatan kontekstual merupakan suatu konsep belajar dimana guru menghadirkan situasi nyata ke dalam kelas dan mendorong siswa membuat hubungan antara pengetahuan yang dimilikinya dengan penerapannya dalam kehidupan mereka sebagai anggota keluarga dan masyarakat (Nurhadi, dkk, 2003).

Pendekatan kontekstual sebagai pilihan untuk "menghidupkan" kelas, agar siswa belajar dengan sesungguhnya belajar (learning how to learn). Sehingga pada akhirnya diharapkan siswa tidak bosan mengikuti pembelajaran terjadi interaksi multi arah, motivasi siswa meningkat yang bermuara pada peningkatan kreativitas dan pemahaman konsep volum dan luas sisi bangun ruang khususnya dan pelajaran matematika pada umumnya.

Penelitian ini berguna untuk perbaikan mutu pembelajaran matematika khususnya di SMP Negeri 2 Pasongsongan Sumenep. Pemilihan metode pembelajaran yang sesuai dengan situasi dan kondisi sekolah merupakan salah satu alternatif untuk memberikan pemahaman konsep matematika dan menimbulkan kreativitas siswa.

\section{METODE}

\section{Rancangan Penelitian}

Pada dasamya PTK terdiri dari 4 (empat) tahapan dasar yang saling terkait dan berkesinambungan. Empat tahapan tersebut adalah : (1) planning (perencanaan tindakan); (2) implementing (pelaksanaan tindakan); (3) observing (pengamatan tindakan); (4) reflecting (refleksi terhadap tindakan). Namun sebelumnya, tahapan ini diawali oleh suatu tahapan pra-PTK, yang meliputi : (1) identifikasi masalah; (2) analisis masalah; (3) rumusan masalah; (4) rumusan hipotesis tindakan. Tahapan 
pelaksanaan PTK digambarkan secara skema sebagai berikut :

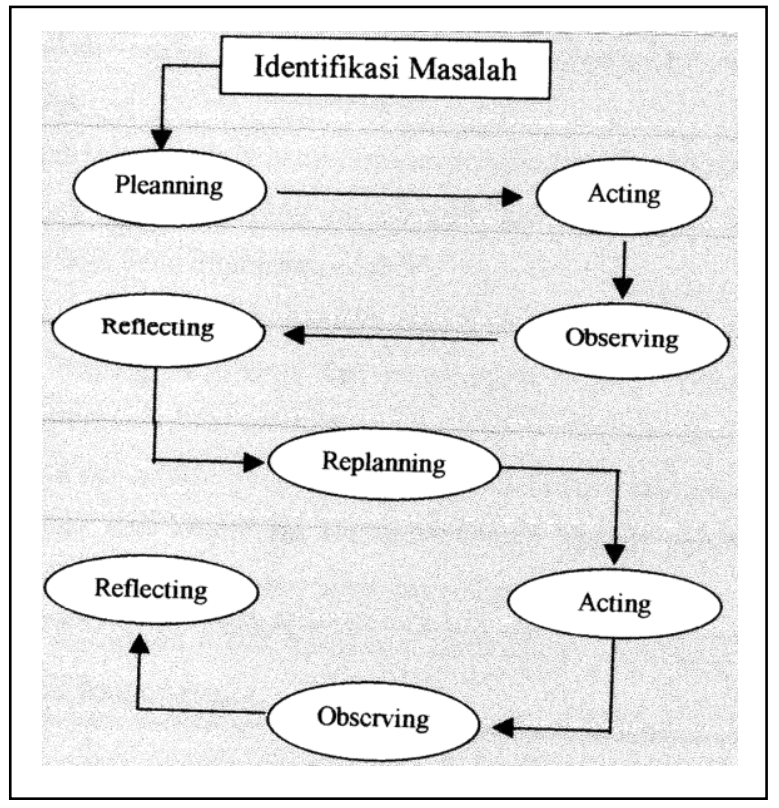

Gambar 1. Skema Pelaksanaan PTK

(Sumber : Kristono, 2000)

\section{Setting Penelitian}

Penelitian ini berlangsung di SMP Negeri 2 Pasongsongan Sumenep yakni kelas 3 dengan jumlah siswa 38 . Penelitian dilakukan pada semester I pada pokok bahasan volum dan luas, sisi bangun ruang.

Sebagai peneliti adalah guru matematika kelas 3 di SMP Negeri 2 Pasongsongan Sumenep, waktu penelitian dilaksanakan pada bulan juli sampai dengan bulan agustus 2012 .

\section{Persiapan Penelitian}

Dalam tahap persiapan penelitian tindakan kelas (PTK), kegiatan yang dilakukan adalah :

1. Menyusun perangkat dan model pembelajaran yang mendukung rencana penelitian ini.

2. Mempersiapkan alat bantu yang akan dipergunakan dalam pembelajaran.

3. Menyusun skenario pembelajaran.

4. Menyiapkan instrumen penelitian berupa format observasi, LKS, angket dan soal tes.
5. Menyediakan media pemodelan sebagai implementasi dari pendekatan kontekstual.

6. Penguasaan teknik-teknik pembelajaran dengan pendelcatan kontekstual.

Merujuk dari tujuan yang ingin dicapai dalam penelitian ini, maka teknik pengumpulan data yang digunakan adalah

1. Observasi, yang digunakan penulis untuk memperoleh data dari pengamatan langsung tentang kreativitas dan pemahaman konsep volum dan luas sisi bangun ruang.

2. Wawancara dan angket yang digunakan penulis untuk memperoleh data obyek tak langsung dari kreativitas dan pemahaman konsep volum dan luas sisi bangun ruang serta tanggapan siswa tentang penerapan metode kontekstual.

3. Tes yang digunakan untuk mengukur kemampuan penerapan konsep volum dan luas sisi bangun ruang. 


\section{Siklus Penelitian}

Pada penelitian tindakan kelas ini penulis merencanakan tindakan sebanyak 2 siklus, dimana setiap siklus terdiri dari rangkaian kegiatan : (1) perencanaan; (2) pelaksanaan; (3) observasi; (4) analisis data; (5) refleksi.

Siklus pertama dilakukan dengan menggunakan pemodelan yakni guru membawa model-model bangun ruang di dalam kelas.

\section{Rencana Tindakan Siklus Pertama}

1. Menyusun perangkat dan model pembelajaran yang mendukung rencana penelitian ini.

2. Mempersiapkan instrumen pengumpulan data berupa lembar monitoring observasi kelas, angket, LKS dan soal test.

3. Menyusun skenario pembelajaran.

4. Mempersiapkan model-model bangun ruang.

\section{Pelaksanaan Tindakan Siklus Pertama}

1. Melakukan tanya jawab dengan pokok bahasan bangun-bangun datar sebagai salah satu prasyarat untuk dapat mengikuti materi pelajaran volum dan luas bangun ruang.

2. Memberikan motivasi dan penggunaan pendekatan pembelajaran kontekstual dalam mata pelajaran matematika.

3. Melaksanakan kegiatan pembelajaran sesuai dengan skenario pembelajaran yang telah disusun guru.

4. Memberikan angket/lembar wawancara.

5. Melakukan pengamatan dan melakukan pencatatan mengenai perubahan-perubahan yang terjadi selama proses pembelajaran.

6. Mencatat hal-hal yang perlu untuk diperbaiki atau ditindak lanjuti pada siklus selanjutnya.

\section{Refleksi Siklus Pertama}

1. Mencatat dan merekam hasil tanya jawab.
2. Merangkum/mencatat hasil observasi dan wawancara dengan siswa.

3. Mencatat kejadian-kejadian yang kurang relevan untuk diperbaiki pada siklus ke 2 .

4. Menganalisa data-data yang berupa hasil tanya jawab, tes evaluasi, observasi dan wawancara.

5. Membuat kesimpulan.

Siklus kedua dilakukan dengan melibatkan siswa secara aktif dalam pembelajaran. Dalam melakukan pembelajaran dengan pendekatan kontekstual pada siklus kedua ini siswa dilibatkan untuk membuat sendiri model-model bangun ruang.

\section{Rencana Tindakan Siklus Kedua}

1. Merevisi tindakan-tindakan yang kurang relevan di siklus pertama.

2. Membentuk siswa dalam kelompok-kelompok.

3. Mempersiapkan media pembelajaran.

4. Mempersiapkan tugas-tugas yang akan diterapkan baik secara perorangan maupun kelompok.

\section{Pelaksanaan Tindakan Siklus Kedua}

1. Melaksanakan kegiatan pembelajaran sesuai dengan skenario pembelajarannya.

2. Memaksimalkan kerja kelompok agar siswa yang mampu bisa membimbing siswa yang kurang mampu dengan pemberian tugas-tugas kelompok.

3. Melakukan pengamatan dan pencatatan tentang hasil kerja siswa dalam membuat model-model bangun ruang.

4. Melaksanakan evaluasi pada. akhir siklus kedua.

\section{Refleksi Siklus Kedua}

1. Mengelola data-data berupa hasil observasi monitoring, angket dan nilai ulangan harian.

2. Mencatat kejadian-kejadian yang terjadi yang kurang relevan untuk diperbaiki pada pengajarang selanjutnya. 
3. Membuat kesimpulan dari data-data yang diperoleh.

\section{HASIL DAN PEMBAHASAN \\ Hasil}

1. Siklus ke I (pertama)

Siklus I merupakan pembelajaran volum kubus dan balok dengan menggunakan pemodelan benda bangun ruang. Sesuai dengan karakteristik pembelajaran dengan pendekatan kontekstual, pemodelan merupakan salah satu dari 7 komponen utama pendekatan kontekstual. Tahap pelaksanaan siklus pertama (ke 1) adalah sebagai berikut :

a. Tahap Perencanaan (Planning)

Tahap ini diawali dengan beberapa perencanaan diantaranya

- Mempersiapkan alat bantu pemodelan, yaitu bangun ruang kubus dan balok.

- Merencanakan alokasi waktu pertama yaitu 3 jam pelajaran (120 menit).

- Mempersiapkan lembar observasi beberapa catatan lapangan.

- Mempersiapkan pedoman pertanyaan untuk mengetahui pemahaman siswa tentang pengertian volum kubus dan balok.

b. Tahap pelaksanaan (implementing)

Pada bagian ini pelaksanaan pembelajaran dalam upaya meningkatkan kreativitas dan pemahaman konsep volum dan luas bangun ruang, melalui pendekatan kontekstual guru mengefektifkan penggunaan alat bantu (pemodelan) pembelajaran yang sesuai dengan materi yang diajarkan.

Penggunaan alat bantu (pemodelan) diperagakan oleh guru sendiri dan siswa memperhatikan peragaan.

Adapun skenario pembelajaran pada siklus I adalah sebagai berikut
- Pada tahap pendahuluan, dimulai dengan mengingatkan kembali siswa mengenai hal-hal yang berhubungan dengan kubus dan balok. Guru menanyakan kepada siswa tentang konsep bangun datar yang telah mereka peroleh dan perbedaan antara bangun datar dan bangun ruang. Pertanyaan tersebut meliputi rumus-rumus bangun datar seperti persegi, persegi panjang, segitiga dan lingkaran. Sebagian besar siswa mampu mengingat dan menjawab dengan benar.

- Selanjutnya guru mengenalkan alat bantu yang akan digunakan sebagai pemodelan pada pembelajaran volum kubus dan balok.

- Guru menunjukkan/memperagakan model kubus dan balok (yang sudah dibuat guru) untuk membimbing siswa dalam menemukan konsep rumus di depan kelas, seluruh siswa diminta untuk mengamati model bangun ruang yang diperagakan guru sambil memperagakan guru mengajukan penanyaan kepada siswa, agar siswa mudah untuk menjawab, guru mengajukan pertanyaan kepada siswa. Agar siswa mudah untuk menjawab, guru menunjukkan bagian dari model kubus dan balok sesuai dengan yang ditanyakan.

- Kemudian guru mengajukan lagi penanyaan kepada siswa agar lebih mantap tentang bagian-bagian dari kubus dan balok.

- Bersama-sama dengan siswa guru membuat kesimpulan tentang pengertian kubus dan balok serta menemukan rumus volume untuk kedua, bangun tersebut.

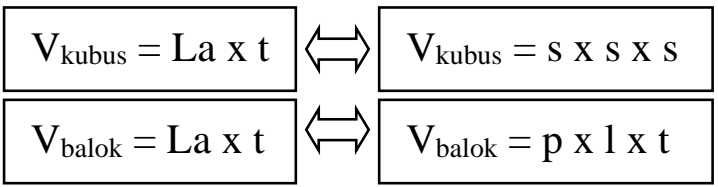


- Setelah rumus ditemukan guru bersama siswa membahas contoh soal kemudian siswa mengerjakan soal latihan.

- Sementara siswa mengerjakan soal guru berkeliling melihat pekerjaan siswa dan membantu siswa yang mengalami kesulitan.

- Pada akhir pembelajaran guru bersama siswa membuat suatu rangkuman, kemudian siswa diberikan tugas rumah.
- Sebelum usai jam pelajaran guru mengajukan pertanyaan sesuai dengan instrumen yang telah disusun dan harus dijawab siswa dikertas lembaran dan dikumpulkan.

c. Tahap Pengamatan (Observing) Pada tahap ini guru yang sekaligus sebagai observer dan peneliti, mendapatkan beberapa data dari catatan lapangan dari pelaksanaan tindakan siklus I dalam kreativitas, dan pemahaman konsep siswa, hasilnya dapat dilihat sebagai berikut.

Hasil pengamatan terhadap kreativitas siswa dengan 7 indikator pada siklus I adalah :

\begin{tabular}{|c|c|c|c|c|}
\hline \multirow{2}{*}{ No } & \multirow{2}{*}{ Indikator } & \multicolumn{3}{|c|}{ Hasil Observasi } \\
\hline & & Baik & Cukup & Kurang \\
\hline 1. & Keseriusan siswa & $\begin{array}{c}30 \\
(79 \%)\end{array}$ & $\begin{array}{c}8 \\
(21 \%)\end{array}$ & - \\
\hline 2. & Inisiatif bertanya & - & $\begin{array}{c}10 \\
(26,3 \% \\
)\end{array}$ & $\begin{array}{c}28 \\
(73,7 \%)\end{array}$ \\
\hline 3. & $\begin{array}{l}\text { Partisipasi siswa dalam } \\
\text { pembelajaran }\end{array}$ & $\begin{array}{c}6 \\
(15,8 \% \\
)\end{array}$ & $\begin{array}{c}10 \\
(26,3 \% \\
)\end{array}$ & $\begin{array}{c}22 \\
(57,9 \%)\end{array}$ \\
\hline 4. & $\begin{array}{l}\text { Kemampuan siswa } \\
\text { menyebutkan fakta }\end{array}$ & - & $\begin{array}{c}20 \\
(52,6 \% \\
)\end{array}$ & $\begin{array}{c}18 \\
(47,4 \%)\end{array}$ \\
\hline 5. & $\begin{array}{l}\text { Kemampuan siswa } \\
\text { menjelas- kan konsep } \\
\text { dengan kata-kata } \\
\text { sendiri }\end{array}$ & - & $\begin{array}{c}9 \\
(23,7 \% \\
)\end{array}$ & $\begin{array}{c}29 \\
(76,3 \%)\end{array}$ \\
\hline 6. & Berdiskusi & - & $\begin{array}{c}8 \\
(21 \%)\end{array}$ & $\begin{array}{c}30 \\
(79 \%)\end{array}$ \\
\hline 7. & $\begin{array}{l}\text { Kemampuan siswa } \\
\text { menemukan dan } \\
\text { menerapkan rumus }\end{array}$ & - & $\begin{array}{c}10 \\
(26,3 \% \\
)\end{array}$ & $\begin{array}{c}28 \\
(74,7 \%)\end{array}$ \\
\hline
\end{tabular}

Hasil evaluasi terhadap pemahaman konsep volum kubus dan balok.

\begin{tabular}{|l|l|c|c|}
\hline No & \multicolumn{1}{|c|}{ Indikator } & $\begin{array}{c}\text { Mampu } \\
\text { menjawab }\end{array}$ & $\begin{array}{c}\text { Mengalami } \\
\text { kesulitan }\end{array}$ \\
\hline 1. & $\begin{array}{l}\text { Mampu menghitung } \\
\text { diagonal bidang dan }\end{array}$ & $\begin{array}{c}30 \\
(79 \%)\end{array}$ & $\begin{array}{c}8 \\
\text { ruang }\end{array}$ \\
2. & $\begin{array}{l}\text { Mampu menghitung luas } \\
\text { alas kubus dan balok }\end{array}$ & 29 & 9 \\
3. & $\begin{array}{l}\text { Mampu menghitung } \\
\text { volum } \\
\text { Kubus }\end{array}$ & 20 & $(23,6 \%)$ \\
18 & $(52,6 \%)$ & $(47,4 \%)$ \\
\hline
\end{tabular}




\begin{tabular}{|l|c|c|} 
4. \begin{tabular}{l|c|} 
Marnpu menghitung \\
volum \\
Balok
\end{tabular} & 23 & 15 \\
\hline
\end{tabular}

\section{d. Perenungan/refleksi terhadap tindakan (reflecting).}

Berdasarkan hasil yang diperoleh dari pengamatan dan catatan lapangan, untuk kreativitas dari pemahaman konsep tentang volum kubus dan balok perlu perbaikan karena secara klasikal ketuntasan belajarnya kurang dari $85 \%$. Kesimpulannya perlu dilaksanakan, siklus II.

\section{Siklus ke II (kedua)}

Dalam siklus kedua ini pelaksanaan proses pembelajaran melibatkan siswa secara aktif untuk membuat model-model bangun ruang dalam hal ini adalah kubus, balok dan prisma segitiga.

Siklus ke II merupakan tindakan pemecahan masalah dari siklus I yaitu pembelajaran volum kubus dan balok dengan menggunakan pendekatan kontekstual. Tahap pelaksanaan siklus kedua adalah sebagai berikut.

a. Tahap perencanaan tindakan (planning) tahap ini di awali dengan beberapa perencanaan, yaitu :

- Menyusun RP/skenario pembelajaran untuk siklus II.

- Mempersiapkan media pembelajaran, yaitu :

- Plastik transparan warna-warni.

- Gunting/cutter.

- Penggaris.

- Benang warna.

- Lem UHU.

- Membagi siswa dalarn kelompok-kelompok.

- Membuat instrumen pengumpul data.

- Menyiapkan soal tes.

b. Tahap pelaksanaan tindakan (implementing)

Skenario pembelajaran yang dilaksanakan pada siklus ke II adalah sebagai berikut :

- Pada tahap pendahuluan guru mempersiapkan media/bahan yang akan dipergunakan sebagai pernodelan bangun ruang yaitu kubus, balok dan prisma. Bahan-bahan yang perlu dipersiapkan oleh guru dan siswa (per kelompok) adalah : plastik transparan, gunting, spidol transparan, penggaris, benang warna, lem UHU dan lembar kerja siswa.

- Siswa dibagi dalam kelompok-kelompok dan individu dalam pencatatan, (satu kelompok terdiri dari 3-4 orang).

- Guru bertindak sebagai fasilitator, memberikan informasi yang dibutuhkan bila perlu.

- Guru memberikan langkah-langkah cara membuat model bangun ruang yaitu dengan membuat jaring-jaring kubus, balok dan prisma dahulu baru dibentuk menjadi sebuah bangun ruang.

- Guru menyuruh masing-masing kelompok untuk membuat model-model bangun ruang yang telah ditetapkan yaitu kubus, balok dan prisma.

- Guru menetapkan ukuran bangun ruang yang harus dibuat siswa, yakni:

$>$ Kubus dengan ukuran sisi $6 \mathrm{~cm}$.

> Balok dengan ukuran panjang $10 \mathrm{~cm}$, lebar $7 \mathrm{~cm}$ dan tinggi $5 \mathrm{~cm}$.

$>$ Prisma segitiga : sisi alas adalah segitiga siku-siku sama kaki dengan panjang kaki dari segitiga tersebut adalah $6 \mathrm{~cm}$ dan tinggi prisma 6 . Dengan dibimbing guru, diarahkan agar siswa dapat menemukan rumus volum prisma yakni $\mathrm{V}_{\text {prisma }}=\mathrm{L}$ alas $\mathrm{x}$ tinggi

Setelah rumus ditemukan guru bersama siswa menentukan volum bangun ruang yang baru dibuat.

Selanjutnya siswa diberikan soal-soal latihan. 
$>$ Guru berkeliling melihat siswa mengerjakan soal latihan dan memberikan bimbingan kepada siswa yang mengalami kesulitan.

Pada akhir pelajaran guru memberikan tes dan angket sesuai dengan perencanaan penelitian.

c. Pengamatan tindakan (observing)

Pengamatan dilakukan pada setiap pelaksanaan tindakan dalam kegiatan pembelajaran dengan menggunakan instrumen yaitu : (1) pengamatan terhadap siswa; (2) pengamatan terhadap kerja kelompok; (3) evaluasi kreativitas dan pemahaman konsep siswa; (4) angket untuk mengetahui dampak model pembelajaran dengan pendekatan kontekstual terhadap kreativitas dan pemahaman konsep siswa.

Hasil pengamatan yang dilakukan oleh peneliti dari pelaksanaan tindakan pada siklus kedua dalam kreativitas dan pemahaman konsep dengan mengefektifkan alat bantu model-model bangun ruang yang dibuat siswa sendiri dapat dilihat sebagai berikut:

Hasil pengamatan terhadap kreativitas siswa dengan 7 indikator pada siklus 2 adalah :

\begin{tabular}{|c|c|c|c|c|}
\hline \multirow{2}{*}{ No } & \multirow{2}{*}{ Indikator } & \multicolumn{3}{|c|}{ Hasil Observasi } \\
\hline & & Baik & Cukup & Kurang \\
\hline 1. & Keseriusan siswa & $\begin{array}{c}38 \\
(100 \%)\end{array}$ & - & - \\
\hline 2. & Inisiatif bertanya & $\begin{array}{c}10 \\
(26,3 \%)\end{array}$ & $\begin{array}{c}18 \\
(47,4 \%)\end{array}$ & $\begin{array}{c}10 \\
(26,3 \%)\end{array}$ \\
\hline 3. & $\begin{array}{l}\text { Partisipasi siswa dalam } \\
\text { pembelajaran }\end{array}$ & $\begin{array}{c}28 \\
(73,7 \%)\end{array}$ & $\begin{array}{c}10 \\
(26,3 \%)\end{array}$ & - \\
\hline 4. & $\begin{array}{l}\text { Kemampuan siswa } \\
\text { menyebutkan fakta }\end{array}$ & $\begin{array}{c}24 \\
(63,2 \%)\end{array}$ & $\begin{array}{c}12 \\
(31,5 \%)\end{array}$ & $\begin{array}{c}2 \\
(5,3 \%)\end{array}$ \\
\hline 5. & $\begin{array}{l}\text { Kemampuan siswa } \\
\text { menjelas- kan konsep } \\
\text { dengan kata-kata } \\
\text { sendiri }\end{array}$ & $\begin{array}{c}24 \\
(63,2 \%)\end{array}$ & $\begin{array}{c}12 \\
(31,5 \%)\end{array}$ & $\begin{array}{c}2 \\
(5,3 \%)\end{array}$ \\
\hline 6. & Berdiskusi & $\begin{array}{c}26 \\
(68,4 \%)\end{array}$ & $\begin{array}{c}8 \\
(21,1 \%)\end{array}$ & $\begin{array}{c}4 \\
(10,5 \%)\end{array}$ \\
\hline 7. & $\begin{array}{l}\text { Kemampuan siswa } \\
\text { menemukan dan } \\
\text { menerapkan rumus }\end{array}$ & $\begin{array}{c}30 \\
(79 \%)\end{array}$ & $\begin{array}{c}4 \\
(10,5 \%)\end{array}$ & $\begin{array}{c}4 \\
(10,5 \%)\end{array}$ \\
\hline
\end{tabular}

Hasil evaluasi terhadap pemahaman konsep volum kubus, balok dan prisma.

\begin{tabular}{|c|l|c|c|}
\hline No & \multicolumn{1}{|c|}{ Indikator } & $\begin{array}{c}\text { Mampu } \\
\text { menjawab }\end{array}$ & $\begin{array}{c}\text { Mengalami } \\
\text { Kesulitan }\end{array}$ \\
\hline 1. & $\begin{array}{l}\text { Mampu mengitung volum } \\
\text { kubus }\end{array}$ & 37 & 1 \\
2. & $\begin{array}{l}\text { Mampu menghitung volum } \\
\text { balok }\end{array}$ & 35 & $(2,60 / 6)$ \\
3. & $\begin{array}{l}\text { Marnpu menghitung volum } \\
\text { prisma }\end{array}$ & $\begin{array}{c}92,10 \%) \\
34\end{array}$ & $\begin{array}{c}(7,90 / 6) \\
(89,50 \%)\end{array}$ \\
\hline
\end{tabular}


Penilaian berdasarkan angket yang diberikan kepada siswa.

Sikap kegemaran siswa terhadap model pembelajaran yang telah diikuti.

\begin{tabular}{|l|c|c|}
\hline \multirow{2}{*}{ Pertanyaan } & \multicolumn{2}{|c|}{ Jawaban Siswa } \\
\cline { 2 - 3 } & Senang & $\begin{array}{c}\text { Tidak } \\
\text { senang }\end{array}$ \\
\hline $\begin{array}{l}\text { Siswa senang belajar } \\
\text { dengan } \\
\text { pendekatan kontekstual }\end{array}$ & 34 & 4 \\
$(89,5 \%)$ & $(10,5 \%)$ \\
\hline
\end{tabular}

Manfaat pembelajaran volum kubus, balok dan prisma terhadap kehidupannya.

\begin{tabular}{|l|c|c|}
\hline \multirow{2}{*}{ Pertanyaan } & \multicolumn{2}{|c|}{ Jawaban Siswa } \\
\cline { 2 - 3 } & Senang & $\begin{array}{c}\text { Tidak } \\
\text { senang }\end{array}$ \\
\hline $\begin{array}{l}\text { Siswa merasakan } \\
\text { kegunaan } \begin{array}{l}\text { pembelajaran yang baru } \\
\text { dilakukan dalam } \\
\text { kehidupannya. }\end{array}\end{array}$ & $\begin{array}{c}33 \\
(86,8 \%)\end{array}$ \\
\hline
\end{tabular}

Pendapat siswa apakah model pembelajaran yang telah diikuti perlu sering digunakan.

\begin{tabular}{|l|c|c|}
\hline \multirow{2}{*}{ Pertanyaan } & \multicolumn{2}{|c|}{ Jawaban Siswa } \\
\cline { 2 - 3 } & Senang & $\begin{array}{c}\text { Tidak } \\
\text { senang }\end{array}$ \\
\hline $\begin{array}{l}\text { Siswa memerlukan metode } \\
\text { pendekatan kontekstual } \\
\text { seperti } \\
\text { yang telah dilakukan. }\end{array}$ & $\begin{array}{c}36 \\
(94,7 \%)\end{array}$ & $\begin{array}{c}2 \\
(5,3 \%)\end{array}$ \\
\hline
\end{tabular}

Pendapat siswa apakah dengan model pembelajaran kontekstual merasa tertantang.

\begin{tabular}{|c|c|c|}
\hline \multirow[b]{2}{*}{ Pertanyaan } & \multicolumn{2}{|c|}{ Jawaban Siswa } \\
\hline & Senang & $\begin{array}{c}\text { Tidak } \\
\text { senang }\end{array}$ \\
\hline $\begin{array}{l}\text { Siswa. tertantang dengan } \\
\text { langkah- } \\
\text { langkah pembelajaran yang } \\
\text { baru } \\
\text { dilakukan. }\end{array}$ & $\begin{array}{c}36 \\
(94,70 / 6)\end{array}$ & $\begin{array}{c}2 \\
(5,30 / 6)\end{array}$ \\
\hline
\end{tabular}

Pendapat siswa apakah metode pembelajaran yang telah dilakukannya menarik.

\begin{tabular}{|c|c|c|}
\hline \multirow{2}{*}{ Pertanyaan } & \multicolumn{2}{|c|}{ Jawaban Siswa } \\
\hline & $\mathrm{Ya}$ & Tidak \\
\hline $\begin{array}{ll}\text { Siswa tertarik } & \text { dengan } \\
\text { metode } & \\
\text { pembelajaran } & \text { dengan } \\
\text { pendekatan } & \\
\text { Kontekstual } & \end{array}$ & $\begin{array}{c}34 \\
(89,5 \%)\end{array}$ & $\begin{array}{c}4 \\
(10,5 \%)\end{array}$ \\
\hline
\end{tabular}

Dari pengamatan guru terhadap fingkat pemahaman siswa terhadap volum dan luas bangun ruang. Diperoleh data sebagai sebagai berikut. 


\begin{tabular}{|c|c|c|}
\hline \multirow{2}{*}{ Jenis Pertanyaan } & \multicolumn{2}{|c|}{ Kemampuan Siswa } \\
\cline { 2 - 3 } & Senang & $\begin{array}{c}\text { Tidak } \\
\text { senang }\end{array}$ \\
\hline $\begin{array}{l}\text { Soal-soal tertertulis } \\
\text { tentang } \\
\begin{array}{l}\text { volum kubus, balok dan } \\
\text { prisma }\end{array}\end{array}$ & $93 \%$ & $7 \%$ \\
\hline
\end{tabular}

Interview (wawancara)

Setelah selesai kegiatan pembelajaran, guru memanggil beberapa siswa sebagai sampel untuk diwawancarai. Wawancara ini sebagai cek silang terhadap angket yang disebarkan ke siswa, maka dalam memilih responden diambil yang mewakili karakteristik siswa dalam kelas tersebut. Adapun hasil wawancara sebagian besar siswa menjawab sesuai dengan jawaban diangket yang telah mereka isi.

\section{Pembahasan}

Data yang telah diperoleh dari hasil pengamatan pada siklus II diolah dan di analisis dengan hasil sebagai berikut :

1) Dari data penilaian tentang kreativitas dengan 7 indikator, didapat bahwa pada siklus I 5(13,5\%) siswa baik, $11(28,2 \%)$ siswa cukup dan $22(58,3 \%)$ siswa kurang. Tetapi pada siklus II ada peningkatan kreativitas siswa, yaitu 26(67,7\%) siswa baik, $9(24,1 \%)$ siswa cukup dan hanya $3(8,2 \%)$ siswa kreativitasnya masih kurang. Hal ini menunjukkan bahwa penggunaan model pembelajaran dengan pendekatan kontekstual pada pokok bahasan volum dan luas sisi bangun ruang memberikan kontribusi yang cukup signifikan (positif) terhadap peningkatan kreativitas siswa.

2) Sebanyak $34 \quad(89,5 \%)$ siswa merasakan, bahwa pembelajaran dengan pendekatan kontekstual menyenangkan dan hanya $4(10,5 \%)$ siswa menyatakan bahwa pembelajaran dengan pendekatan kontekstual membosankan. Hal ini dapat dipahami karena hampir 33
$(86,8 \%)$ menyatakan bahwa pembelajaran volum dan luas bangun ruang dengan pendekatan kontekstual bermanfaat dalam kehidupannya dan hanya $5(13,2 \%)$ menyatakan tidak bermanfaat.

Dengan demikian sangat logis jika sebagian besar $36(94,7 \%)$ siswa menyatakan bahwa pembelajaran volum dan luas bangun ruang dengan pendekatan kontekstual itu perlu dan hanya sebagian kecil 2 (5,3\%) menyatakan tidak perlu.

Sebagian besar $36(94,7 \%)$ siswa menyatakan bahwa pembelajaran volum dan luas sisi bangun ruang dengan pendekatan kontekstual itu menantang dan hanya sebagian kecil $2(5,3 \%)$ siswa menyatakan tidak menantang. Dengan demikian amat logis jika sebagian besar $34(89,5 \%)$ siswa menyatakan bahwa pembelajaran tersebut menarik dan hanya $4(10,5 \%)$ menyatakan tidak menarik.

3) Setelah mengalami pembelajaran volum dan luas bangun ruang dengan pendekatan kontekstual pemahaman konsep siswa terhadap volum balok, volum kubus dan volum prisma lebih baik. Hal ini ditunjukkan dari 38 siswa, 93\% mampu menjawab soal dengan benar dan hanya $7 \%$ siswa mengalami kesulitan.

4) Bagi siswa yang belum tuntas setelah siklus II sebanyak 3(7\%) siswa diberikan bimbingan tersendiri di luar jam pelajaran. Kegiatan remidial ini dilakukkan setelah jam terakhir dengan metode bimbingan mandiri dengan pendalaman materi dan oemberian tugas-tugas. 
5) Kesimpulannya karena ketuntasan belajar lebih besar dari $85 \%$ maka siklus III tidak dilanjutkan.

\section{KESIMPULAN DAN SARAN Kesimpulan}

Berdasarkan uraian yang telah penulis kemukakan dalam bab-bab sebelumnya, dapat disimpulkan hal-hal sebagai berikut :

1. Pembelajaran volum dan luas sisi bangun ruang dengan pendekatan kontekstual memiliki efektivitas yang tinggi untuk mengembangkan aspek kreativitas (afektif) dan pemahaman konsep (kognitif) bagi siswa SMP.

2. Pembelajaran volum dan luas sisi bangun ruang dengan pendekatan kontekstual mengintensifkan interaksi siswa dengan kehidupan nyata (bendabenda, konkrit) dan teman sebayanya serta guru, sehingga dapat menarik minat dan menyenangkan siswa.

3. Pemahaman konsep volum bangun ruang lebih baik dan mantap.

4. Penggunaan pendekatan kontekstual merupakan sesuatu yang baru bagi siswa, sehingga dapat menarik perhatian, menumbuhkan motivasi dan minat belajar matematika umumnya, yang akhirnya dapat meningkatkan kualitas proses dan hasil belajar siswa.

5. Kegiatan merencanakan dan membuat model-model bangun ruang dari bahan yang tersedia sangat mengasyikkan siswa dan tidak membosankan karena setiap kali mereka dapat membuat kombinasi baru mengikuti daya imajinasinya sehingga prinsip dari berpikir kreatif (kreativitas) terpenuhi.

\section{Saran}

Agar metodologi pembelajaran dengan pendekatan kontekstual dapat berjalan secara efektif dan efisien, maka perlu diperhatikan hal-hal sebagai berikut d. Mempersiapkan alat (bahan) media dengan seksama dan teliti.

e. Menyusun skenario pembelajaran dengan seksama.

f. Membentuk siswa dalam kelompok-kelompok.

g. Menyusun lembar kerja yang baik.

h. Memberikan kebebasan kepada siswa untuk berkreasi sesuai dengan imajinasinya.

i. Susunlah tahap demi tahap dengan menentukan/mentapkan waktu untuk masing-masing tahapan.

j. Hargailah setiap hasil karya siswa.

k. Diperlukan kreativitas dan keterampilan guru dalam menyusun skenario pembelajarannya.

1. Kepada rekan-rekan guru diharapkan untuk dapat mengimplementasikan pendekatan kontekstual/CTL dalam pelajaran matematika pada pokok bahasan-bahasan yang lain.

\section{DAFTAR PUSTAKA}

Bobbi Deporter and Mike Hernachi, 2000, Quantum learning, Kaifa, Bandung.

Departemen Pendidikan dan Kebudayaan, 1993, Kurikulum Pendidikan Dasar, GBPP 1994, Mata Pelajaran Matematika, DEPDIKBUD, Jakarta.

Gordon Dryden dan Jeanette VOS, Dr, 2000, Revolusi Cara Belajar, Kaifa, Bandung.

Hamid Muhammad, 2004, Kebijakan Pemerintah Dalam, Penyelenggaran Kurikulum 2004, Makalah disajikan dalam seminar sehari implementasi kurikulum. 2004 ; Dutara Harapan dan Kenyataan di Sumenep.

ISPI, 1998, Bahan Temu Karya Pendidikan Nasional, Jakarta.

Kistono, AR. 2000, Action Research : Suatu kebutuhan guru untuk meningkatkan mutu proses dan hasil belajar, Depdiknas Propinsi Jawa Timur, Surabaya. 
Nurhadi, dkk, 2003, Pembelajaran Kontekstual dan Penerapannya Dalam KBK, Universitas Negeri Malang, Malang

Samsul Bahri, dkk, 2001, Materi Pelatihan PKGSJ, Kanwil Dinas Pendidikan Propinsi Jawa Timur, Surabaya.

Sudjana, S.H.D. 2001, Metode dan Teknik Pembelajaran Partisipatif, Falah Production, Bandung.

Toto Sudiharto, dkk, 1998, Sumber Belajar, Pusat Sumber Belajar (PSB), IKIP Malang, Malang.

Utami Munandar, S.C, 1992, Mengembangkan Bakat dan Kreativitas Anak Sekolah, P.T. Gramedia Widya Sarana Indonesia, Jakarta. Wardani , I.G.K. Dr, Dkk, 2004, Penelitian Tindakan Kelas, Pusat Penerbitan Universitas Terbuka Departemen Pendidikan Nasional, Jakarta.

Wardani, I.G.K. Dkk, 2004, Penelitian Tindakan Kelas, Pusat Penerbitan Universitas Terbuka Departemen Pendidikan Nasional, Jakarta.

Winarno Surakhmad,1994, Pengantar Interaksi Belajar Mengajar, Tarsito Bandung. 